\title{
'A FESTERING SORE ON THE BODY OF SOCIETY': THE WOLFENDEN COMMITTEE AND FEMALE PROSTITUTION IN MID-TWENTIETH-CENTURY SCOTLAND
}

\author{
ROGER DAVIDSON AND GAYLE DAVIS
}

\section{Introduction}

The proceedings and report of the Wolfenden Committee on Prostitution and Homosexual Offences (1954-7) figure prominently in the historiography of the sexual politics of late twentieth-century Britain. In terms of female prostitution, three broad but inter-related strands of interpretation may be detected within the literature. First, a largely narrative approach has located the Committee and subsequent legislation within the broader story of changing sexual mores and associated moral panic in 1950s Britain. ${ }^{1}$ Secondly, many social historians and sociologists have focused upon the coercive and regulatory implications of the report and the Street Offences Act of 1959, often within a Foucauldian framework of analysis. For commentators such as Jeffrey Weeks, the Wolfenden Report, by redefining the relationship of the law to the private moral terrain of the citizen, enabled a reaffirmation of the policing of public space in the interests of order and decency. $^{2}$ Similarly, for Frank Mort, one of its most significant features was its codification of a 'new geography of sexuality' which both made the 'troublesome and dangerous sexualities of prostitution' more visible to the official mind and furnished a new 'topography of regulation'. ${ }^{3}$ Meanwhile, other commentators have advanced a more specifically feminist interpretation of events. Thus, Carol Smart views the central thrust of the Wolfenden Committee's deliberations on

\footnotetext{
${ }^{1}$ See, e.g., L. Hall, Sex, Gender and Social Change in Britain since 1880 (London, 2000), Ch. 9; C. Haste, Rules of Desire: Sex in Britain:World War 1 to the Present (London, 1992), Ch. 7; P. Ferris, Sex and the British:A Twentieth-Century History (London, 1993), Ch. 8.

2 J. Weeks, Sex, Politics and Society: The Regulation of Sexuality since 1800 (2nd edn, Harlow, 1989), 243-4.

${ }^{3}$ F. Mort, 'Mapping Sexual London: The Wolfenden Committee on Homosexual Offences and Prostitution 1954-57’, New Formations, 37 (1999), 92-113, especially 94-5.
} 
prostitution and the Street Offences Act as the control of women's sexuality. ${ }^{4}$ Within this framework of analysis, they constituted part of a more general reassertion of the ideologies of family life and motherhood in the 1950s, which sustained 'women's position within the patriarchal order' and which served to elevate the prostitute into 'a new folk devil in spite of an apparent liberation of female sexuality in discourses on sex'. ${ }^{5}$

However, in the main, existing research has centred on the social politics of the Wolfenden Committee at a national level in Westminster and Whitehall, and its implications for sexual law reform in England, and there is a notable lack of regional studies. It is important to recognise that, while its proceedings may have focused on metropolitan concerns south of the Border, they also involved a Scottish dimension. Both written and oral evidence was presented to the Committee by a range of Scottish civil servants, law officers, medical experts, and social workers; evidence that was shaped by distinctive traditions of law, local government, and medical practice in Scotland, as well as arguably a distinctive civic and sexual culture.

This article has four main objectives. First, it utilises this evidence to document the existing provisions for the prosecution and treatment of female 'prostitutes' in mid-twentieth-century Scotland. Secondly, it investigates the forces and arguments both for and against the revision of street offences legislation as revealed in the Scottish testimony to the Committee. The article then focuses on the response of Scottish opinion to the recommendations of the Wolfenden Report and to the subsequent exclusion of Scotland from the 1959 Street Offences Act. In conclusion, it seeks briefly to assess the implications of the Scottish experience for any interpretation of the Wolfenden Committee and its role in the developing relationship between sexuality and the State.

\section{The prosecution and treatment of prostitutes}

In the 1950s, female solicitation was prosecuted in Scotland primarily in the police courts, under either the Burgh Police (Scotland) Act of 1892 or a variety of local corporation orders in the major cities. The usual charge was that, 'being a common prostitute or streetwalker', the accused 'loiter[ed] about or importune[d] for the purposes of prostitution'. ${ }^{6}$ In addition, a wide range of byelaws regulating public parks, pleasure grounds, links, seashores and other places of public resort included provisions against soliciting. ${ }^{7}$ The Licensing Acts were also employed to reduce the

\footnotetext{
${ }^{4}$ C. Smart, 'Law and the Control of Women's Sexuality: The Case of the 1950s', in B. Hutter and G. Williams (eds), Controlling Women: The Normal and the Deviant (London, 1981), 40-60.

${ }_{5}$ Ibid., 45, 48. See also, H. J. Self, Prostitution, Women and Misuse of the Law: The Fallen Daughters of Eve (London, 2003).

${ }^{6}$ National Archives of Scotland (hereafter NAS), HH 60/268, memo. submitted by Scottish Home Department, 'Prostitution and Allied Offences', Oct. 1954.

7 Ibid.
} 
number of prostitutes operating out of hotels and public houses. ${ }^{8}$ In addition, some police authorities, such as Edinburgh, were prepared to charge kerb-crawlers with disorderly behaviour and to employ 'girls in plain clothes as agents provocateurs'.

Penalties varied across the country. Outwith the cities, the maximum penalty for a first offence would typically be 40/- with imprisonment for up to twenty days for non-payment. In Edinburgh, however, the penalty was as much as $\mathcal{E} 10$ for a first offence, or alternatively imprisonment for up to sixty days. Imprisonment was used more extensively in Scotland than in England and Wales with some 20\% of proven charges for female importuning in Scotland in the early 1950s incurring imprisonment, either for repeat offences or non-payment of fines. ${ }^{10}$

Several other significant features distinguished the law and practice relating to female prostitution in Scotland - many of which had been commended by the 1927 Macmillan Committee on Street Offences, ${ }^{11}$ and were also to provide a role model for the Wolfenden Committee. First, whereas in England and Wales, an offence of soliciting had to be 'to the annoyance of the inhabitants or passengers', this requirement was absent from Scots Law, greatly facilitating the prosecution process and avoiding the manufacture of false charges by the police, which was a perennial complaint south of the Border. Secondly, accusations of police corruption and discrimination surrounding issues of vice were less frequent in Scotland because a Procurator-fiscal and not the police had the responsibility of initiating prosecutions in the public interest, and the uncorroborated evidence of one witness was not sufficient to prove a charge, as was the case in England and Wales. ${ }^{12}$

Thirdly, in Scotland, only after surveillance and several cautions was a woman charged in court as a 'common prostitute'; a process previously recommended for the whole of the United Kingdom by the Macmillan Committee. ${ }^{13}$ Thus, in Glasgow, if a woman was suspected of being a prostitute, her behaviour was monitored by the police, and if she was seen to importune or accost three or more individuals, she was warned that, if she persisted, she might be apprehended. Particulars of this caution were recorded by the officer in his official note-book. If the woman repeated the offence, she was apprehended and taken to the police station where she was formally cautioned. Only if, after both cautions, she repeated the offence, was she brought before the court, where the record of her conduct

\footnotetext{
${ }^{8}$ Thus, the Licensing (Scotland) Act of 1903 made it a condition of a license that the holder should not 'knowingly permit or suffer men or women of notoriously bad fame ... to assemble' in the licensed premises.

${ }^{9}$ The National Archives, Public Record Office, Kew (hereafter PRO), Proceedings of the Wolfenden Committee (hereafter PWC), HO 345/16, evidence of Assistant Chief Constable (hereafter ACC) for Edinburgh, 10 Apr. 1956.

${ }^{10}$ NAS, HH 60/268, memo. submitted by Scottish Home Department, 'Prostitution and Allied Offences', Oct. 1954.

${ }_{11}$ Report of the Street Offences Committee, PP, 1928-9 (Cmd. 3231), IX, 13, 16, 24-5.

${ }^{12}$ NAS, HH 60/268, memo. submitted by Scottish Home Department, 'Prostitution and Allied Offences', Oct. 1954.

${ }^{13}$ Report of the Street Offences Committee, PP, 1928-9 (Cmd. 3231), IX, 24.
} 
served as presumptive evidence that she was a 'common prostitute' ${ }^{14}$ A similar system operated in Edinburgh, but here the woman was given two cautions on the street before being taken to the police station. ${ }^{15}$

Furthermore, a major feature of the Scottish cautioning system was its close association with the 'rescue work' of moral welfare agencies. In Glasgow, there was a long-standing liaison between the police authorities and the Women's Help Society. Representatives of the Society regularly patrolled at night with the plainclothes police and obtained particulars of girls being warned or cautioned for the purpose of follow-up visits, especially to the younger women observed loitering on the streets. In addition, at various stages of the cautioning and prosecution processes, the police would routinely refer suspected prostitutes to the voluntary societies in the hope of some form of moral reclamation. ${ }^{16}$ Similarly close links between moral welfare agencies and the Burgh Courts existed in Edinburgh and Dundee, with a social welfare officer employed by the Church of Scotland to counsel women cautioned or charged with street offences. ${ }^{17}$

However, elements of care and compassion in the treatment of female soliciting were often counterbalanced, not only by concerns for the policing of public space and the avoidance of public nuisance, but by anxieties over public health. The body of the prostitute long continued to preoccupy policy-makers as the key vector of venereal disease, with a consequent erosion of her civil liberties. Under the Criminal Justice (Scotland) Act of 1949, courts were empowered to remand sexual offenders for a medical examination, or to make it a condition of bail. ${ }^{18}$ Scottish Law Officers subsequently ruled that such powers were intended as an aid to sentencing and not infectious disease control. ${ }^{19}$ However, in the 1950 s it was common practice for so-called 'habitual prostitutes' either to be routinely remanded in custody for medical examination and treatment for VD, or to be referred to the VD clinics, irrespective of whether they had any symptoms. ${ }^{20}$ Similarly, under the

${ }^{14}$ PRO, HO 345/16, PWC, evidence of ACC for Glasgow, 10 Apr. 1956. In some parts of Scotland the cautionary process started afresh if a woman was free from conviction for two years.

${ }^{15}$ Ibid., PWC, evidence of ACC for Edinburgh, 10 Apr. 1956.

16 Report of the [Wolfenden] Committee on Homosexual Offences and Prostitution (hereafter RWCHP), PP, 1956-7 (Cmnd. 247), XIV, 91; PRO, HO 345/9, PWC, memo. by Christine Mackenzie, 1956; HO 345/16, evidence of Mackenzie, 9 Apr. 1956; HO 345/16, evidence of Magistrates of Corporation of Glasgow, 9 Apr.1956.

${ }_{17}$ Church of Scotland, Report of Church and Nation Committee to General Assembly, $1958,421$.

18 Criminal Justice (Scotland) Act, 1949, 12, 13, \& 14 GEO. 6, CH 94, s. 27.

19 NAS, HH 57/568, minute by Dr I. D. Inch, 'Treatment of Venereal Diseases in Prison: General Questions', 10 and 18 Apr. 1961.

${ }^{20}$ Ibid. It was observed that, in England and Wales, it was commonly believed that a prison sentence for prostitution was primarily 'imposed when the police suspect[ed] that the woman [had] some venereal disease' (T. E. James, Prostitution and the Law (Altrincham, 1951), 112). One argument subsequently levelled against the Street Offences Act by the Scottish Prison Medical Service was that by driving prostitutes off the streets it would weaken the ability of the police and public health authorities to monitor key vectors of venereal disease. Interestingly, evidence from court and clinic records suggests that, while Section 27 of the Criminal Justice Act was commonly used to refer homosexual offenders for psychiatric appraisal, which frequently mitigated the sentences imposed, this 
Children and Young Persons (Scotland) Act of 1937, girls and young women whose sexual promiscuity was thought to presage a life of prostitution were commonly remanded for medical investigation and routinely examined for VD on their first admission to a remand home or approved school, or on any readmission after absconding, or after returning from a holiday or home visit. ${ }^{21}$

\section{Proponents of fresh legislation}

Scottish members of the Wolfenden Committee, and a range of Scottish witnesses giving evidence, regarded the existing tariff of penalties for soliciting as derisory. The penalty for a first offence in most Scottish Burghs of a $£^{2}$ fine was regarded as 'totally inadequate as a deterrent' and 'nothing short of a laughing stock' ${ }^{22}$ Many witnesses endorsed the view of the influential Committee member, James Adair, a former Procurator-fiscal, Chairman of the Scottish Council of the YMCA, and long-serving elder of the Church of Scotland, that the regular prostitute 'invariably had her 40/- fine tucked away, to be produced at the police station if she was arrested; she could then get her release on bail. The fine was part of the oncost' ${ }^{23}$ It was claimed that, as a result, coupled with the fact that, as in London, the police only operated a system of rotating arrests, prostitution in the major Scottish cities was effectively being condoned.

For many witnesses before the Committee, the solution was not just an increase in the level of fines, which might merely serve as an incentive for prostitutes to increase the number of their clients, but imprisonment. Although imprisonment was used more extensively in Scotland for street offences relating to prostitution, Scottish law officers and the police strongly urged before the Wolfenden Committee that prison sentences should be more regularly imposed on offenders as a deterrent. According to the Glasgow Magistrates, 'the only thing that [would] disturb their quiet serenity [was] imprisonment' ${ }^{24}$ while women police and prison officers in Scotland wanted prison sentences extended as they claimed that short sentences tended to be treated 'as a rest cure' ${ }^{25}$ An additional benefit, it was argued,

option was rarely adopted in cases of female solicitation despite significant advances in the psychopathology of prostitution. See, e.g., the highly influential work of E. Glover, The Psycho-Pathology of Prostitution (London, 1945).

${ }^{21}$ NAS, ED 48/1364, Joint memo. by the Home Office and Scottish Home Department on the Rehabilitation of Young Prostitutes, 1943; R. Davidson, Dangerous Liaisons: A Social History of Venereal Disease in Twentieth-Century Scotland (Amsterdam \& Atlanta, 2000), 276.

${ }^{22}$ PRO, HO 345/4, PWC, note by J. Adair, 1955.

${ }^{23}$ PRO, HO 345/6, PWC, 'Notes on General Discussion', 21 Feb. 1956. See also, HO 345/16, evidence of Magistrates of Corporation of Glasgow, 9 Apr. 1956: 'A $£ 2$ fine is useless - they either have it stacked away or one of their coterie will pay it.' Similarly, PRO, HO 345/16, evidence of Christine Mackenzie, 9 Apr. 1956: 'They have a kitty. I was visiting one a short time ago, and she said to me:"It is all right if I am caught out again. I will get my money paid.",

${ }^{24}$ PRO, HO 345/16, PWC, evidence of Glasgow Magistrates, 9 Apr. 1956.

${ }^{25}$ PRO, HO 345/15, PWC, evidence of Director of Scottish Prison and Borstal Services, 1 Nov. 1954. 
was that the prostitute was effectively compelled, if imprisoned, to submit to examination and treatment at aVD clinic, to the benefit of public health.

Many of the Scottish Churches, along with women's organisations and moral welfare agencies, also advocated a greater use of imprisonment for soliciting offences, although their rationale was more a concern to secure for first offenders a period of self-reflection and moral rehabilitation before they progressed to being 'hardened prostitutes'. Thus, Christine Mackenzie, Warden of the Glasgow Women's Help Committee, advocated a sixty-day prison sentence for a first offence: 'I feel very strongly about it. I do feel there are some who could see another way of living if they were just removed for sixty days. ${ }^{26}$

This strongly resonated with the views of Mary Cohen, another Scottish member of the Wolfenden Committee, former Chairman of the Scottish Association for Girls' Clubs, and long-standing member of the National Vigilance Association for Scotland, who proposed that prostitutes under twenty-one on first conviction should:

not be fined but put under probation and detained in a centre for some days for social and medical examination (partly to detect venereal disease and mental defectiveness); during this time probation officers and others would have an opportunity to talk with the girl and rescue her. ${ }^{27}$

Perhaps the greatest consensus amongst Scottish Committee members and witnesses was the need for increased penalties for pimps, procurers and propertyowners living on immoral earnings. There was a widespread concern that the law should anticipate the greater organisation and off-street commercialisation of prostitution consequent on street offences legislation. A range of proposals for countering the growth of 'call-girl rackets' included the increase of penalties for procuring, previously established under the 1885 Criminal Law Amendment Act and 1912 Immoral Traffic Act, ${ }^{28}$ the hearing of such cases before more senior courts, and more stringent targeting by the law of landlords who let accommodation for the purposes of prostitution. ${ }^{29}$

However, underlying some of the Scottish evidence to the Wolfenden Committee there was an additional strand of disquiet at the moral assumptions and

${ }^{26}$ Ibid., evidence of Christine Mackenzie, 9 Apr. 1956.

${ }^{27}$ PRO, HO 345/10, PWC, 'Note of Discussion', 29 Jan. 1957. Similarly, the Church and Nation Committee of the Church of Scotland favoured penalising soliciting 'by imprisonment in all cases, after due cautioning and welfare work' not just for its 'greater deterrent effect' but as 'an opportunity for spiritual and physical remedial treatment'. See Report of Church and Nation Committee to General Assembly of the Church of Scotland, 1958, 421-2.

${ }_{28}$ As some witnesses somewhat nostalgicly noted, under the 1912 Act, flogging for second or subsequent offences had been sanctioned until 1948.

${ }^{29}$ Both Adair and Cohen submitted reservations to the Wolfenden Report on this issue. Adair was concerned to broaden the range of 'middlemen' who were prosecuted, and to introduce more stringent measures against landlords involved in vice. Cohen recommended that the maximum sentence for living on immoral earnings be raised from two to five years. See RWCHP, 123-4. 
double moral standards underpinning the existing law and legal procedures. Women's organisations such as the Scottish Standing Committee of the National Council of Women, the Association for Moral and Social Hygiene and the Equal Citizenship Group, protested on a number of counts at the gender discrimination inherent in the existing system of prosecution in Scotland.

First, women's organisations considered that the courts were heavily prejudiced against women offenders 'by reason of the statutory nature of the offence'. The words 'being a common prostitute or streetwalker', which appeared in the charge, were said 'to create an impression of guilt'. Accordingly, in line with the recommendations of the 1927 Street Offences Committee, such organisations called for the law of solicitation to be framed so as to apply only to the generic offence and not to the offender, without any specific reference to his/her 'character or sex' ${ }^{30}$

Secondly, female witnesses were outraged that, although in Scotland the Immoral Traffic Act and local statutes such as the Glasgow Police Act applied to importuning by both men and women, they were, in practice, invariably deployed against women. Thus, Christine Mackenzie protested that she had been over thirty-three years in the Glasgow Police Courts and never once seen a man prosecuted under the Police Act. She added with some passion:'I am not a feminist - I would like to say that I am definitely not - but I do feel terrifically strongly when they [men] are a menace, as they are at the moment, and nothing happens. ${ }^{31}$ Similarly, Elizabeth Abbott, a Scot and veteran of the Association for Moral and Social Hygiene, urged the Committee to focus more on the problem of 'male immorality' in their deliberations and to end the systemic discrimination in the application of the law. ${ }^{32}$

While not directly testifying to the Committee, many of the Scottish churches endorsed such sentiments. In particular, the United Free Church associated itself with the concerns of the Association for Moral and Social Hygiene over gender inequalities in the law on solicitation, and called upon the Government to ensure that legislation 'apply on an equal basis to men and women alike' and that procedures should maintain 'the right of all accused to be assumed innocent before conviction' ${ }^{33}$ Likewise, the Congregational Union of Scotland wanted clearer recognition in law that solicitation was also a function of male demand. ${ }^{34}$

\footnotetext{
${ }^{30}$ See, e.g., PRO, HO 345/8, PWC, evidence of E. Abbott, n.d. 1955; HO 345/16, evidence of C. Mackenzie, 9 Apr. 1956; PRO, CAB 129/66, memo. on 'Sexual Offences' by Secretary of State for Scotland, 17 Feb. 1954; Report of the Street Offences Committee, PP, 1928-9 (Cmd. 3231), IX, 21. For a more general discussion of the legal and cultural implications of the retention of the term 'common prostitute', see Smart, 'Law and the Control of Women's Sexuality', 52.

${ }^{31}$ PRO, HO 345/16, PWC, evidence of Christine Mackenzie, 9 Apr. 1956.

${ }_{32}$ PRO, HO 345/8, PWC, evidence of E. Abbott, 1955.

${ }^{33}$ United Free Church of Scotland, Minutes of Proceedings of General Assembly, 1958, 20.

${ }^{34}$ Congregational Union of Scotland, Annual Report of Temperance and Social Questions Committee, $1958-9,119$.
} 


\section{Proponents of the status quo}

Despite such reservations about existing policy towards street offences, the majority of Scottish witnesses before the Wolfenden Committee did not consider that prostitution, and its associated soliciting, presented a serious problem of public nuisance in Scotland. Indeed, their evidence merely endorsed the view expressed as early as February 1954 by the Secretary of State for Scotland that 'there have been no recent indications of public concern about this social evil in Scotland', that he had 'received no representations about it', and that: 'The Scottish problem would not in itself justify an enquiry.' 35

Certainly, evidence from the Scottish police, from law officers, and from moral welfare workers, indicated that prostitution was present in the major urban centres. In Glasgow, prostitution was considered to be well-established within the City centre. For example, one former Procurator-fiscal recollected that in the immediate past:

[Y] ou had your square - Oak Street, Renfrew Street and Gordon Street where you could say you had at least 20 prostitutes - who just went round and round that square - stood at the street corners for a few minutes, and were regularly there, and were regularly accosting individuals who passed ... ${ }^{36}$

However, by the 1950s, the main focus of prostitution in Glasgow was reported to be at the coffee stalls in the central business area of town, which operated from $11 \mathrm{pm}$ to $3 \mathrm{am}$, where prostitutes seeking clients 'could capture crowds coming from late dances and picture houses' and then, charging on average about $\mathcal{L}_{1} \mathrm{a}$ transaction, use the nearby closes for their business. ${ }^{37}$ Although 'the lodging house type - the aged hag' might still patrol the dock area, in the view of Glasgow's Assistant Chief Constable, in the central area the " "old shawlie" type of prostitute' had been largely superceded by a better-dressed, more sophisticated type. ${ }^{38}$ At the same time, it was observed that there was an absence in Glasgow of the type of 'high-class prostitute' prevalent in parts of London. ${ }^{39}$

Yet, despite some history of vice rings and evidence of so-called 'call-girl rackets' in Glasgow, in general, it was claimed that prostitution was not organised and not closely involved with the criminal fraternity. ${ }^{40}$ This was attributed by James Adair to the fact that 'the social and economic conditions were different [from London] and there was not the cosmopolitan factor'; one of many references

35 PRO, CAB 129/66, (Sexual Offences): memo. by Secretary of State for Scotland, 17 Feb. 1954.

${ }^{36}$ PRO, HO 345/16, PWC, minutes of proceedings, 9 Apr. 1956.

37 The ACC for Glasgow estimated that there were approximately 120 prostitutes 'plying their trade in Glasgow streets' in 1955. See PRO, HO 345/16, PWC, evidence of ACC for Glasgow, 10 Apr. 1956.

38 Ibid. This was attributed by some witnesses to the disappearance of women's lodging houses.

39 PRO, HO 345/16, PWC, evidence of Glasgow Magistrates, 9 Apr. 1956.

${ }^{40}$ PRO, HO 345/16, PWC, evidence of ACCs for Glasgow and Edinburgh, 10 Apr. 1956. 
to the alleged role of immigrants - especially Greek Cypriots - in organised vice. ${ }^{41}$

In Edinburgh, the Crown Agent's view was that 'there [were] certain streets where one would know where to look' for prostitutes - for example, in the Leith Dock area and Saxe-Coburg Street in Stockbridge - but that it was not comparable to the problem in London and, 'except in some of the quieter streets', there was not 'much accosting going on'. ${ }^{42}$ The coffee stalls that proved such a focus for prostitution in Glasgow had been abolished in Edinburgh after the war. As in Glasgow, there was, he claimed, evidence of an influx of prostitutes when major exhibitions and other events - notoriously the General Assembly of the Church of Scotland! - were held in the City and they 'occasionally follow[ed] the fleet up from Plymouth'. However, there were, he stressed, no 'serious problems' in Edinburgh cafes or public houses and little evidence of organised brothels. ${ }^{43}$ In his experience, the main issues of public concern were the prevalence of kerbcrawling in Queen Street and the West End, and the association of very young girls with American servicemen.

Other evidence suggests that the Edinburgh police authorities were almost certainly in some considerable degree of denial when testifying to the Wolfenden Committee. Their view was not shared by the Edinburgh Magistrates Committee who believed there had been a significant shift of "certain activities ... from the streets to public houses and other places of public resort' ${ }^{44}$ One commentator later recorded that at the Imperial Hotel in Leith Walk 'there would be fifteen hookers and the place would be absolutely stinking of hairspray and beehives'. At the Deep Sea Fish and Chips:

It was all communal tables and the loo opened directly into the dining room and you could sit there and see everybody going out and in and the whores would drag in whatever trick they had managed to grab. There was a subterranean lavvy outside ... and the gay guys and the hookers all just used it, slipped downstairs and used the boxes. I think money more than likely passed hands from the hookers to the police. ${ }^{45}$

Certainly, an analysis of the District Court records indicates that the police were primarily targeting prostitution in the central areas of Edinburgh and operating what appears to have been a virtual tolerance zone in Leith. Few prosecutions for female solicitation in the Leith area are recorded for the years 1950-5, whereas some $90 \%$ of prosecutions related to offences in Princes Street and the surrounding area, including George Street, Frederick Street, Leith Street, and Rose Street. ${ }^{46}$

${ }^{41}$ PRO, HO 345/6, PWC, 'Notes on General Discussion', 21 Feb. 1956.

${ }^{42}$ PRO, HO 345/16, PWC, evidence of L. Gordon, Crown Agent, 9 Apr. 1956.

${ }^{43}$ Ibid.

44 Edinburgh City Archives, Minutes of Magistrates Committee, 18 Nov. 1954.

${ }^{45}$ Bob Cant, Footsteps and Witnesses: Lesbian and Gay Lifestories from Scotland (Edinburgh, 1993), 52.

${ }^{46}$ Edinburgh City Archives, District Court Papers for 1950-5. 
Very little was recorded of the incidence of prostitution elsewhere in Scotland. While there was reportedly no 'resident problem' in the West of Scotland outwith Glasgow, it was alleged that train loads of prostitutes did migrate to the area from Glasgow when 'a troopship was due in Greenock or an American vessel arrive[d]'. ${ }^{47}$ Similar migrations were associated with the American base near Prestwick and with the dockyard at Rosyth. ${ }^{48}$ Certainly, Mary Cohen, one of three Scottish members of the Wolfenden Committee, regarded 'the crowds of women and girls rushing to naval ports and various camps' in Scotland as 'equally degrading spectacles in their respective areas' as the 'Common Prostitutes in Curzon Street', while her fellow Committee member, James Adair, was concerned to extend existing Burgh legislation relating to soliciting to cover military establishments in rural areas. ${ }^{49}$ Some evidence suggested that outwith Glasgow and Edinburgh, the problem lay more with 'amateur good-time girls' rather than

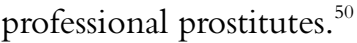

However, while acknowledging the existence of prostitution north of the Border, the weight of Scottish evidence presented to the Wolfenden Committee was that its prevalence did not present 'the same magnitude of problem' as in London either with regard to street offences or the conduct of brothels. Baillie Duncan of Glasgow considered that its problem was 'the least for an industrial city' while the Assistant Chief Constable of Edinburgh considered that prostitution in Edinburgh 'was no problem whatever' ${ }^{51}$ For their part, the Faculty of Advocates testified that:

They do not consider that there is any reason to suppose that, in Scotland [Street Offences] are carried on to such an extent or in such a manner as to affect general standards of conduct, or so as to give grounds for apprehension that these types of immorality are on the increase. ${ }^{52}$

Such arguments were strongly reinforced by statistics supplied by the Scottish Home Department on the incidence of prosecutions for importuning in Scotland (see Figure 1). ${ }^{53}$ These indicated a long-term decline in prosecutions, with the annual average number of cases for the years 1950-5 representing only about onethird of that for the inter-war period. This was in marked contrast to the apparent threefold rise in recorded offences of female solicitation in England and Wales. ${ }^{54}$

47 PRO, HO 345/16, PWC, evidence of ACCs for Glasgow and Edinburgh, 10 Apr. 1956.

48 Ibid.

49 PRO, HO 345/5, PWC, M. Cohen to J. Wolfenden, 30 July 1956; HO 345/10, 'Note of Discussion', 29 Jan. 1957.

${ }^{50}$ PRO, HO 345/16, PWC, evidence of L. Gordon, Crown Agent, 9 Apr. 1956.

51 PRO, HO 345/16, PWC, evidence of Glasgow Magistrates, 9 Apr. 1956; evidence of ACC for Edinburgh, 10 Apr. 1956.

${ }_{52}$ PRO, HO 345/9, PWC, evidence of Faculty of Advocates, 1956.

${ }^{53}$ RWCHP, PP, 1956-7 (Cmnd. 247), XIV, 147.

54 Ibid., 143 


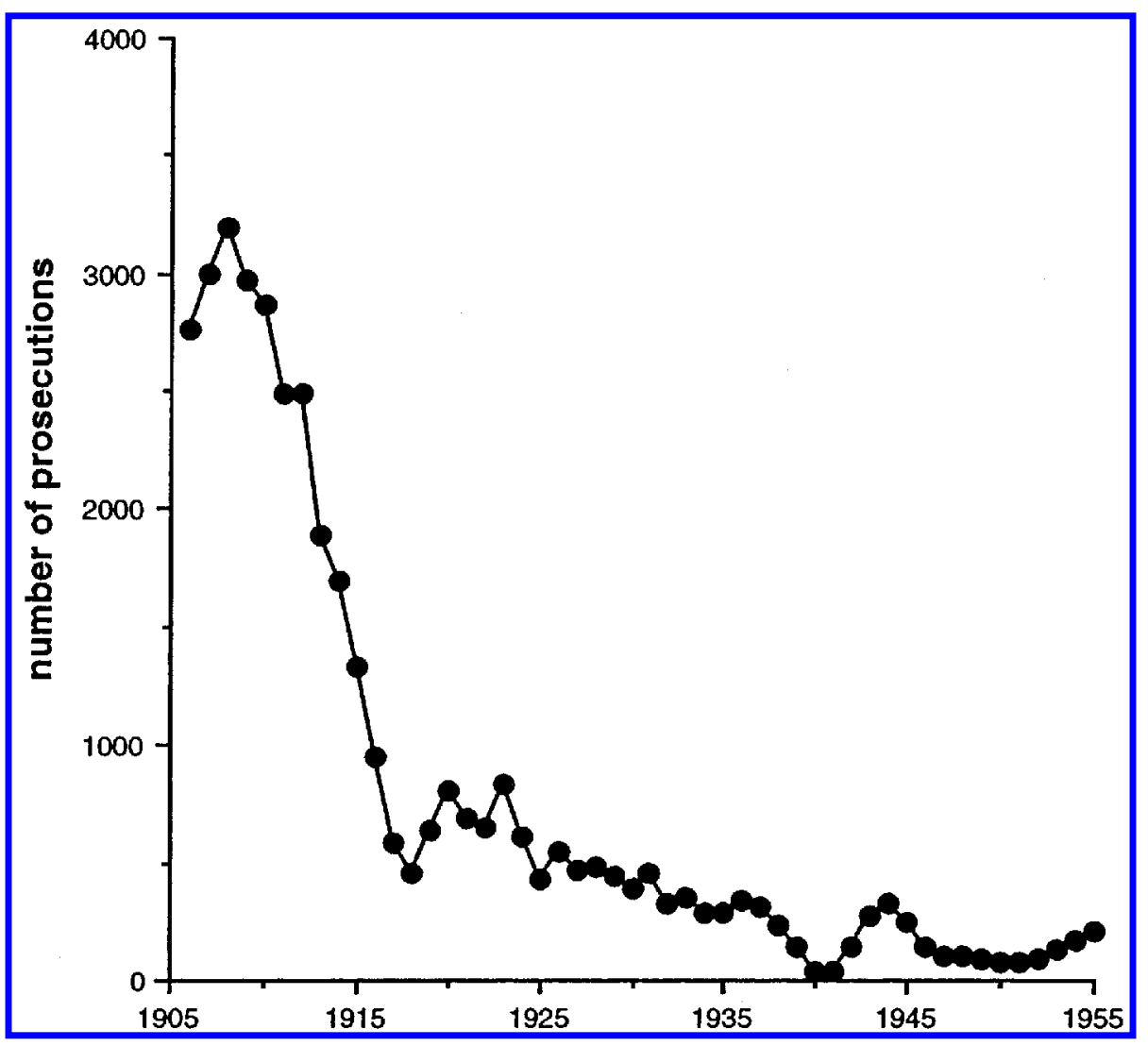

Figure 1. Scottish prosecutions for female solicitation, 1905-55. Source: RWCHP, 147.

Scottish Committee members and witnesses presented a range of explanations for this divergence. Adair considered that it was due less to differences in legal procedures than to the relative size of 'urban concentrations', ${ }^{55}$ while Cohen attributed it to the fact that 'the Scottish way of life ... even in the big cities [was] much simpler and altogether there [was] not so much night life of any kind in Scotland'. ${ }^{6}$ J. Anderson, Deputy Secretary of the Scottish Home Department, suggested that, prima facie, the heavier penalties in Scotland and the absence of a need to prove 'annoyance' might be crucial factors but that there was a lack of any conclusive evidence. ${ }^{57}$ Meanwhile, Glasgow Magistrates Committee submitted that, while the media might focus 'more on sex', standards of morality had in fact risen in Scotland and the incidence of prostitution had been reduced by 'the

${ }_{55}$ PRO, HO 345/12, PWC, Committee proceedings, 15 Oct. 1954.

${ }^{56}$ Ibid.

${ }^{57}$ PRO, HO 345/12, PWC, evidence of Scottish Home Department, 15 Oct. 1954. 
higher physical standard of the community and the greater degree of economic security women [had] generally'. ${ }^{58}$

Not only was the problem of prostitution not perceived as sufficiently acute in Scotland to merit fresh legislation, many witnesses before the Wolfenden Committee considered that the existing Scottish penalties and procedures for dealing with female solicitation were both more efficient and humane, and generally more consistent with civil liberties than those operating in England and Wales. Scottish law and practices on the issue were thus perceived more as a template for action south of the Border than as a suitable case for revision.

Thus, testimony focused on the degree to which the different laws of evidence and prosecution procedures in Scotland not only facilitated legal action against prostitution in Scotland but also reduced the number of allegations of corruption levelled at the police in their regulation of vice. ${ }^{59}$

The higher level of fines and prison sentences imposed by Scottish burgh and district courts for female solicitation was also cited in defence of the status quo. ${ }^{60}$ The Scottish Home Department and the police authorities were satisfied that they had procedures in place to deal with more recent developments in the 'vice trade'. In particular, they were convinced that the powers devolved under the licensing and public order acts were sufficient to curb the use of hotels and public houses for prostitution and the prevalence of kerb-crawling. ${ }^{61}$

Scottish law officers were also hostile to the proposals of women's organisations and moral welfare agencies to extend the provisions of probation and remand for 'rescue' purposes. They concurred with Adair's view that 'non-punitive detention could not be defended'. ${ }^{62}$ In fact, the Scottish police did 'not think that the intervention of moral welfare workers [had] much effect'. ${ }^{6}$ In many respects the evidence of moral welfare workers themselves served to undermine the strength of their recommendations. They conveyed the strong impression that the new generation of prostitutes was better off and 'more sophisticated', and that it was motivated more by idleness than economic necessity and resistant to traditional rescue work. Young prostitutes in particular were perceived as deliberately choosing prostitution as a way of life and as 'unlikely to respond to moral persuasion' ${ }^{64}$ The limited evidence presented by Scottish psychologists merely served to reinforce such impressions. Thus, in the view of Winifred Rushforth, Director

${ }^{58}$ PRO, HO 345/16, PWC, evidence of Glasgow Magistrates, 9 Apr. 1956.

59 NAS, HH 60/268, PWC, written submission of Scottish Home Department, Oct. 1954.

${ }^{60}$ Ibid.

${ }^{61}$ Ibid.; PRO, HO 345/16, PWC, evidence of ACCs for Edinburgh and Glasgow, 10 Apr. 1956.

${ }^{62}$ PRO, HO 345/10, PWC, 'Notes of Discussion', 29 Jan. 1957.

63 PRO, HO 291/123, 'Notes for debate on the Wolfenden Report', 1957-8.

${ }^{64}$ See, e.g., PRO, HO 291/123, 'Notes for Debates on Wolfenden: Redemption of Young Prostitutes', 1957-8; HO 345/16, PWC, evidence of Christine Mackenzie, 9 Apr. 1956. She also lamented the inability of moral welfare workers to facilitate medical support as they had in the past: 'They do not require that, because with penicillin the problem has ... been solved, unfortunately for them.' 
of the pioneering Davidson Clinic in Edinburgh, established in 1940 to provide psychotherapeutic treatment to the general public, prostitutes were 'usually unsuitable patients' for treatment. In her view, they were often 'unintelligent, dull or psychopathic' and she had 'never found them at all helpful' in her counselling work. $^{65}$

In addition, the evidence of senior Scottish Law officers, including the Crown Agent, and heavily supported by Adair, favoured the retention of the designation 'common prostitute' in the charge for soliciting, as an essential protection against 'an innocent woman' being charged. They refused to acknowledge that the habitual male client should be in an analogous legal position. ${ }^{66}$ Despite clear evidence of the lack of prosecutions against men for soliciting, the law officers stressed that, in Scotland, in contrast to England and Wales, male importuning of women and children was expressly an offence. However, the main thrust of their resistance on this issue was that Scottish legal procedures ensured that the status of 'common prostitute' could only be designated after an extensive process of surveillance and cautioning which involved close liaison with the moral welfare agencies. ${ }^{67}$ Again, the existing treatment of female prostitutes in Scotland was upheld as an example for the rest of the United Kingdom in balancing care and coercion in the regulation of what were deemed to be 'dangerous sexualities'.

\section{The Wolfenden Report and its aftermath in Scotland}

In its eventual report to Parliament in September 1957, the Wolfenden Committee recommended a mix of punitive and reformatory measures designed to facilitate the prosecution of street offences, increase the penalties for repeated solicitation, and bring the law to bear more effectively against brothel-keepers and landlords living on immoral earnings. More specifically, the Committee proposed that there should no longer be a need to establish 'annoyance' in the prosecution of soliciting; that the maximum penalties for street offences be increased, and that a system of progressively higher penalties for repeated offences be introduced; that stricter powers should be introduced enabling the courts to rescind the tenancy rights of those using premises for the purposes of habitual prostitution and to indict

${ }^{65}$ PRO, HO 345/7; HO 345/16, PWC, written and oral evidence of Dr Winifred Rushforth, n.d. 1955, 10 Apr. 1956.Venereologists frequently expressed similarly stereotypical views. Thus, in the view of Robert Lees, Physician-in-Charge of Edinburgh'sVD services, prostitution attracted 'only the lazy, self-indulgent, thoughtless, and mentally unbalanced types, devoid of affection or loyalties and indifferent to the future' (Annual Report of the Edinburgh Public Health Department, 1959, 143). Significantly, little evidence on the medical aetiology and treatment of prostitution was elicited by the Wolfenden Committee. Indeed, while the medical treatment of male homosexual offenders was explicitly part of its terms of reference, this was not the case with respect to female prostitutes.

${ }_{66}$ PRO, HO 345/7, PWC, evidence of Glasgow Stipendary Magistrate, n.d. 1955; HO 345/16, evidence of Crown Agent, 9 Apr. 1956; HO 345/16, comment of J. Adair in questioning Christine Mackenzie, 9 Apr. 1956.

${ }^{67}$ PRO, HO 345/16, PWC, evidence of Glasgow Magistrates, 9 Apr. 1956; evidence of ACCs for Edinburgh and Glasgow, 10 Apr. 1956. 
landlords who charged exorbitant rents for such premises with living on immoral earnings; that a more formal system of cautioning prostitutes, as in Edinburgh and Glasgow, should be introduced prior to prosecution, and that particulars of a prostitute cautioned for the first time should be referred to a moral welfare worker; that courts be given explicit power to remand, in custody if need be, for not more than three weeks, a prostitute convicted for the first or second time of a street offence, in order that a social or medical report might be obtained; and that researches be instituted into the aetiology of prostitution. ${ }^{68}$

At Westminster, some Scottish peers and MPs objected to the thrust of the Wolfenden Report and to its legislative proposals. For example, Lord Kilmuir acknowledged that the presence of prostitutes on the street was 'offensive to the ordinary citizen's sense of decency' and 'injurious' both as an example to girls and as a needless temptation to their male clients. However, he considered that, in addition to specific measures, there was an urgent need 'to raise the social and moral outlook of society as a whole'. ${ }^{69}$ Somewhat more eccentrically, Lord Saltoun, while opposed to the propensity of the British public in its 'virtuous brutality' to 'harry the whore' off the streets, counselled a curious mix of Christian charity and a regularised system of maison tolerées which might accord British prostitutes 'some sort of respect'. ${ }^{70}$ More orthodox Liberal objections came from the Liberal leader, Jo Grimond, and Lord Balfour of Burleigh. Jo Grimond criticised the Wolfenden Report and draft legislation for callously ignoring the systemic economic and social causes of prostitution, for undervaluing the civil liberties of female prostitutes, and for failing to address the moral and legal liability of male clients and the likely emergence of more sophisticated and exploitative call-girl rackets. ${ }^{71}$ In similar vein, Lord Balfour of Burleigh dismissed the subsequent Street Offences Bill as 'a Pimp's Benefit Bill' which, he argued, resonated with the bigotry of 'former centuries [that] approved the whipping of the harlot at the cart's tail'. Like Grimond, he considered that the bill infringed civil liberties in its use of the designation 'common prostitute' and its asymmetry in the treatment of male and female importuning. For the first time, he protested, it wrote 'the double standard of morality into the Statute Book'. ${ }^{72}$

However, insofar as Scottish opposition was articulated in the parliamentary

${ }^{68} \mathrm{RWCHP}, 116-17$.

${ }^{69}$ Hansard (HL), vol. 206, cols 769-79, 4 Dec. 1957.

${ }^{70}$ Hansard (HL), vol. 217, cols 1190-3, 14 July 1959.

${ }^{71}$ Hansard (HC), vol. 598, cols 1310-11, 29 Jan. 1959.

${ }^{72}$ Hansard (HL), vol. 216, cols 96-101, 5 May 1959; vol. 217, cols 1182-4, 14 July 1959. Meanwhile, the Church of Scotland also expressed fundamental concerns over the ethical assumptions underlying the Wolfenden Committee's remit and recommendations. Its Church and Nation Committee drew attention 'to the possible danger of thinking too much in terms of merely regulating prostitution and the practices connected with it, and of accepting, or appearing to accept, the existence of prostitution as though it were an inevitable and ineradicable social phenomenon'. In the Committee's view, fresh Street Offences legislation might 'merely result in a hypocritical hiding away of prostitution and a convenient ignoring by the community of its existence as a social evil and a scandal ...' See Report of Church and Nation Committee to the General Assembly of the Church of Scotland, 1958, 420-1. 
debates surrounding the Street Offences Bill, the argument was primarily directed at the comparative equity and efficiency of existing legal and social work practices relating to female solicitation north of the Border and at the consequent lack of need for Scotland to be included in fresh legislation. ${ }^{73}$ This strongly echoed the views of the Home Office and Scottish Home Department. Both departments drew a clear conclusion from the Wolfenden Report that the problem was essentially a metropolitan one and that the incidence of prostitution in Scotland could be contained by means of existing measures. Considering the issue in late October 1957, the Secretary of the Scottish Home Department advised the Secretary of State that:

As regards prostitution, the Committee made few criticisms of the existing Scottish law, and their main recommendations were designed to bring the English law closer to the Scottish, which does not require annoyance to be established before an offence is committed, provides higher penalties (including imprisonment) for repeated offences, and automatically terminates any lease of premises used as a brothel or for the purposes of habitual prostitution. ${ }^{74}$

Although the Wolfenden Report had recommended higher and more uniform penalties for solicitation and an amendment of regulations covering places of refreshment, the permanent officials believed that this could readily be effected by local legislation and bye-laws. ${ }^{75}$ The one area where they anticipated Scots Law being out of line was in respect of persons living on immoral earnings, where the maximum sentence recommended by the Committee was five years as compared with the two years operating in Scotland. In public, the Scottish Home Department rationalised this likely discrepancy on the somewhat disingenuous grounds that there was no evidence that the existing law was 'insufficiently severe'. However, the main reason why both the Scottish Law Officers and the Government wanted to preserve the status quo was that the relevant legislation relating to immoral earnings for Scotland, the Immoral Traffic Act, 1902, Section 1, also applied to importuning by males, including for homosexual purposes. As a result, there was acute concern that to alter the penalties for living on immoral earnings north of the Border would simply reactivate public debate over the issue of homosexual law reform and the Government's contentious decision not to decriminalise homosexual practices in accordance with the Wolfenden Report's recommendations. ${ }^{76}$

\footnotetext{
${ }^{73}$ See, e.g., Lord Lothian, Hansard (HL), vol. 206, cols 780-7, 4 Dec. 1957; Jean Mann, Labour MP, Coatbridge, Hansard (HC), vol. 596, col. 402, 26 Nov. 1958; Lord Silkin, Hansard (HL), vol. 216, cols 78-9, 5 May 1959.

${ }^{74}$ NAS, HH 60/265, minute by Sir William Murrie, Secretary, Scottish Home Department to Secretary of State for Scotland, 30 Oct. 1957.

75 Ibid.; NAS, HH 60/265, Notes for Commons Debate on Wolfenden Report, 26 Nov. 1958.

${ }^{76}$ Ibid.
} 
In contrast, some sections of the Scottish media were heavily critical of the omission of Scotland from fresh street offences legislation. A series of articles in the Scotsman in June 1959 questioned the validity of official statistics on the incidence of Scottish prostitution, arguing that it 'remained a festering sore on the body of society', casting 'its infection in many directions' and requiring additional powers for police and public health authorities. ${ }^{77}$ Its reporter found compelling evidence of a rise in female prostitution across Scotland. In Edinburgh, despite the removal of the obvious congregating points such as the old coffee stalls in Princes Street, he encountered a taxi driver who could 'reel off without the slightest hesitation thirty addresses where he knew prostitution could readily be found, in flats near the centre'. He also found widespread evidence of a rising use of bars and cafés for prostitution, often frequented at the weekend by women from the housing schemes and the Lothians, driven into the sex industry by poverty due to unemployment and credit arrears. In Glasgow, similar trends were identified, with 'as many as 40 prostitutes in a limited area of the centre of the City, ... quite brazen about their purpose, standing in groups on the corners of streets'. Apart from the dockside bars, prostitutes were reported to be colonising the poorer tenements in areas such as the Gorbals and Charing Cross where the 'old social order' was disintegrating. There were also indications of a call-girl system operating in the City. ${ }^{78}$

Evidence was also produced which cast doubts on official claims that prostitution was largely absent elsewhere in Scotland. In Dundee, it was claimed that the dramatic rise in the rate of new cases of venereal diseases closely reflected the increase in open soliciting both in the streets and bars in the area adjacent to the docks, with some 60 women known to the police authorities, many of whom were controlled by pimps and/or operating from brothels. In addition, prostitution was said to have gravitated to some of the housing schemes on the outskirts of Dundee as a result of the slum clearances in the city centre. Aberdeen, Perth and Inverness were reported as witnessing similar 'sexual license', fuelled by the demands of the workforces on the local hydro-electric schemes, while the presence of American bases was predicted to have a similar impact on other towns such as Ayr. ${ }^{79}$

In the event, the Street Offences Act of 1959 applied only to England and Wales, and excluded Scotland and Northern Ireland. Heavier and more graduated penalties were introduced for soliciting, and significantly longer terms of imprisonment for living on immoral earnings. While a woman cautioned for soliciting might, under the Act, apply for the caution to be expunged from the public record, powers of caution and arrest were simplified to enable any constable to act without proof of annoyance, as in Scotland. In addition, the Licensing Acts

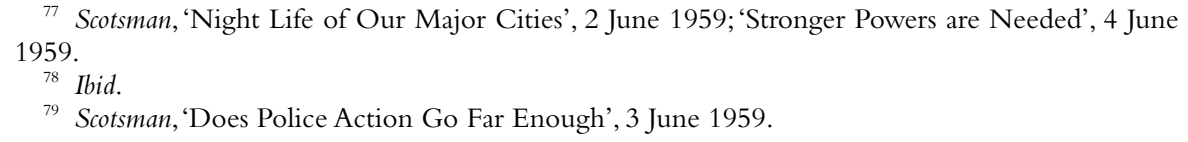


were further deployed to penalise the use of public houses and other places of refreshment for the purposes of prostitution.

Ironically, despite figuring so prominently in the debates surrounding the Wolfenden Report, the Scottish system of cautioning prostitutes and of routinely referring particulars to a moral welfare officer was not incorporated into the Street Offences Act. The Metropolitan Commissioner was not persuaded of the value or appropriateness of such referrals (in part, as a result of the clear ambivalence of the Scottish police authorities in their evidence to the Committee) and preferred to leave it to the Court Probation Officer 'to deal with incipient prostitutes'. ${ }^{80}$ More seriously, English law officers doubted the legality of the cautioning system operated by the Scottish Police. As a Home Office memorandum warned:

The Scottish police can point to no authority except practice for taking prostitutes to the station for the second caution, and it is believed that in England, at any rate, it would be unlawful to arrest a prostitute and take her to the station unless it was intended to charge her and bring her before a magistrate. ${ }^{81}$

Given the degree to which Scottish legal and police procedures had been lauded throughout the debate surrounding street offences legislation, there was more than a hint of relish in the postcript that this should not be publicised 'because it might throw doubt on the legality of the Scottish practice'.

\section{Conclusion}

What are the implications of the Scottish experience for any historical interpretation of the Wolfenden Committee and its role in the developing relationship between prostitution and the State? First, for all the socially disruptive effects of World War II, there are seen to be clear continuities between the ideology and enforcement of policy relating to female solicitation in pre-war Scotland and those prevailing in the 1950s. This was a policy underpinned by a traditional and highly gendered medico-moral sexology that focused on the control of the sexual instinct on the conflation of sexuality and pollution, and on a hierarchy of normality and deviance. As with homosexuality, ${ }^{82}$ the proceedings of the Wolfenden Committee in Scotland continued to position the sexual culture of prostitution primarily as a social pathology.

Secondly, much has been made of the innovative, albeit regulatory, medical and legal discourses of the Wolfenden Committee's proceedings, and its extensive

\footnotetext{
${ }^{80}$ NAS, HH 60/265, minute N. D. Walker to A. B. Hume, 11 Oct. 1957.

${ }^{81}$ PRO, HO 291/123, 'Notes for Debates on Wolfenden: Redemption of Young Prostitutes', $1957-8$.

${ }^{82}$ See R. Davidson and G. Davis, “'A Field for Private Members”: The Wolfenden Committee and Scottish Homosexual Law Reform, 1950-67', Twentieth Century British History, 15 (2004), 174-201.
} 
classification of contemporary sexual pathologies. ${ }^{83}$ Again, however, the Scottish evidence reveals a fundamental attachment to conventional values and perceptions. The medical evidence of agencies such as the Davidson Clinic and the Scottish Prison Service, and the legal testimonies of the Crown Agent and Procurators-fiscal, sometimes embraced new taxonomies of deviance and the psychologisation of prostitution, but remained within a quintessentially 'moral' framework of prescription with respect to policy. They still articulated the traditional rhetoric of degenerationism and social hygiene, and within Scottish governance, public order, public morality, and public health remained inextricably linked both administratively and ideologically.

Thirdly, the history of the Wolfenden Committee and female prostitution in mid-twentieth-century Scotland displays an aversion to fresh legislation which also characterised other areas of sexual debate. As with homosexual law reform, Scots law and legal procedures were widely viewed as a template for action south of the Border rather than as candidates for revision. Just as the processes of evidence and investigation north of the Border were seen to neutralise the more draconic aspects of the criminal law in respect of private, consensual, male homosexual acts, and to mitigate the dangers of police corruption and blackmail, so the mix of care and coercion - of caution, rescue, and prosecution - was seen to satisfy both the punitive and rehabilitative demands of Scottish professional and public opinion in respect of female prostitution. In both instances, such procedures were advanced, albeit at times somewhat disingenously, as a rationale for resisting sexual law reform and for justifying the omission of Scotland from parliamentary legislation..$^{84}$

In part, such a response reflected the marked reluctance of Scottish government to become involved in sexual issues. What emerges is a pattern of government growth where the initiative came not primarily from the centre but from the periphery. As with other areas of sexual offence and sexual health policy in this period, the interface between prostitution and the State was shaped primarily within the local State, by local magistrates and civic leaders and local bye-laws. The personality and proclivities of a Crown Agent or Lord Advocate could clearly be decisive at the end of the day, but the evidence would suggest that it was those, who, in the broadest sense of the term, 'policed' the streets, the clinics, the cafe s, and the docks who proved the major impulses and constraints in the policymaking process.

Finally, the Scottish experience is seen to resonate with both the Foucauldian and feminist approaches to the history of the Wolfenden Committee and asso-

${ }^{83}$ See, especially, Mort, 'Mapping Sexual London', 94-5.

${ }^{84}$ Similarly, there were (unsuccessful) efforts to exclude Scotland from the 1967 Abortion Act, partly on the grounds that there already existed under Scottish common law considerable scope for medical discretion in the provision of terminations. See, G. Davis and R. Davidson, "The Fifth Freedom" or "Hideous Atheistic Expediency"?:The Medical Profession and Abortion Law Reform in Scotland, c.1960-1975', Medical History (forthcoming, 2006). 
ciated debates surrounding female prostitution. The Scottish evidence to the Committee - pre-eminently that of the law officers and magistrates - articulated a predominantly regulatory discourse in which, as in England, ' $[T]$ he desire for the appearance of good order in the streets trumped any concern for the prostitute herself' ${ }^{85}$ Even when, on the few occasions, the social and medical aetiology of prostitution was addressed, it was primarily discussed in terms of psychopathology; as an extreme on the spectrum of sexual regression and dysfunction to be diagnosed and 'modified' in tandem with legal restraints.

As in other areas of Scottish sexual governance, such as sex education, this response was of course heavily gendered. Prostitution continued to be 'constructed' both in legal and medical discourses as quintessentially a female sexual aberration, requiring surveillance, proscription and/or treatment. Although many witnesses called for heavier penalties for male pimps, procurers, and kerb-crawlers, in the main it was the female body of the 'common prostitute', with its perceived moral and physical corruption, that was reaffirmed as the vector of disease and debauchery, and the major threat to public health and order. Moreover, by privileging, in Scotland as in England, the 'voice of the expert witness over the moral campaigner', the Wolfenden Committee successfully marginalised purity and feminist groups which had long campaigned for sexual equality in the formulation and enforcement of street offence legislation. ${ }^{86}$ The 'festering sore on the body of society' so lamented by the Scotsman was destined to remain a heavily gendered metaphor.

\section{Acknowledgements}

The authors wish to thank the Wellcome Trust for their generous support of the research for this article.

\footnotetext{
${ }^{85}$ Hall, Sex, Gender and Social Change, 161.

${ }^{86}$ Ibid.; Mort, 'Mapping Sexual London', 97-8.
} 